Edith Cowan University

Research Online

Research outputs 2014 to 2021

2019

The moderation of gender and generation in the effects of perceived destination image on tourist attitude and visit intention: A study of potential Chinese visitors to Australia

Songshan (Sam) Huang

Edith Cowan University

Robert van der Veen

Follow this and additional works at: https://ro.ecu.edu.au/ecuworkspost2013

Part of the Tourism and Travel Commons

$10.1177 / 1356766718814077$

This is an Author's Accepted Manuscript of: Huang, S., \& van der Veen, R. (2018). The moderation of gender and generation in the effects of perceived destination image on tourist attitude and visit intention: A study of potential Chinese visitors to Australia. Journal of Vacation Marketing, 25(3), 375-389. Available here

This Journal Article is posted at Research Online.

https://ro.ecu.edu.au/ecuworkspost2013/6285 


\title{
The moderation of gender and generation in the effects of perceived destination image on tourist attitude and visit intention: A study of potential Chinese visitors to Australia
}

\author{
Songshan (Sam) Huang* \\ Professor of Tourism and Services Marketing \\ School of Business and Law \\ Edith Cowan University \\ Joondalup, Western Australia \\ Tel: +61 863042742 \\ Email: s.huang@ecu.edu.au \\ and \\ Robert van der Veen \\ Research Fellow, Department of Marketing \\ Oxford Brookes University, Wheatley Campus \\ Wheatley, Oxfordshire, United Kingdom \\ Tel: +44 (0) 1865485682 , Fax: +44 (0)1865 485830 \\ Email: robert.vanderveen@ brookes.ac.uk
}

*corresponding author

\section{Acknowledgements:}

The authors would like to thank Dr Guang Xu, Associate Head of School of Management, Harbin Normal University for his assistance in the data collection.

\begin{abstract}
:
The overall purpose of this study is to examine the moderating roles of gender and generation in the effects of perceived destination image on tourist attitude and visit intention among Chinese potential tourists to Australia. Australia is one of the preferred destinations to Chinese tourists and the China market emerges to be increasingly important to destination marketing organisations in Australia. Echoing the call for more gender studies in the tourism literature and also based on the generation theory, this study employed a cross-sectional questionnaire survey design and used structural equation modelling in its analysis. Survey data were collected through convenience sampling in the Chinese city Harbin at various public venues where urban residents can be found. The study identified Services and Tourism Provisions, Natural Environment, and Quality of Life as three destination image dimensions perceived by Chinese urban residents toward Australia.
\end{abstract}


Services and Tourism Provisions, Natural Environment both positively affected tourist attitude, which in turn levered up visit intention. The study found that the effect of Services and Tourism Provisions on attitude was stronger for men than for women, while the effect of Natural Environment on attitude was stronger for women than for men; for the Post-80s/90s generation, the effect of Natural Environment on attitude was significantly stronger than that for the Post60s/70s generation. Implications for tourism marketers and managers are discussed.

\section{Key words: destination image, tourist attitude, visit intention, gender, generation theory, China; outbound tourism}

\section{Introduction}

Studies on destination image have been abundant in the tourism literature. While early studies focussed more on conceptualising and measuring destination image (e.g., Chon, 1990; Crompton, 1979; Echtner \& Ritchie, 1991), following studies tend to examine more of the causal relations between destination image and its determinants/consequences (e.g., Baloglu, 2000; Baloglu \& McCleary, 1999; Beerli \& Martin, 2004a; Chen \& Tsai, 2007; Chew \& Jahari, 2014; Tavitiyaman \& Qu; 2013; Zhang, Fu, Cai, \& Lu, 2014). It is empirically confirmed that destination image has both cognitive and affective dimensions (Martin \& Bosque, 2008) and each country may have its distinctive set of cognitive destination image toward a specific source market (Huang \& Gross, 2010; Pike, 2002; Tasci, Gartner, \& Cavusgil, 2007).

The literature has generally confirmed that destination image is important in tourists' decision making (Chon, 1990); more specifically, destination image (either cognitive or affective) has been commonly found to be among the predictors of visit intention in different contexts (e.g., Park, Hsieh, \& Lee, 2017; Philips, Asperin, \& Wolfe, 2013; Tavitiyaman \& Qu, 2013; Zhang et al., 2014). However, it is less clear whether destination image directly affects visit intention or exert its influence on visit intention through some mediating variables. While mediators examined in the literature include satisfaction, perceived value, and trip quality, among others (e.g., Chen \& Tsai, 2007; Park et al., 2017; Tavitiyaman \& Qu, 2013; Zhang et al., 2014), a great deal of research has produced evidence to support attitude as a more valid mediator between destination image and visit intention (e.g., Baloglu, 2000; Park et al., 2017; Phillips et al., 2013). According to the Theory 
of Planned Behaviour (TPB) (Ajzen, 1991), attitude could well be an immediate predictor of visit intention.

Gender and generational differences in tourist behaviours have largely been overlooked in tourism studies (Carr, 1999; Han, Meng, \& Kim, 2017; Wang, Qu, \& Hsu, 2016). However, limited evidence in the literature does show that both gender and generation could function to explain differences of tourist behaviours including tourist perceptions of destination image (e.g., Beerli \& Martin, 2004b; Chen \& Kerstetter, 1999; Li, Li, \& Hudson, 2013; Kim, Lehto, \& Morrison, 2007). Therefore, it is meaningful to examine whether gender and generation could possibly moderate the way perceived destination image affects tourist attitude and consequently visit intention.

China is Australia's most valuable tourist market. In 2016, Australia received a total of 1.199 million visitor arrivals from China, making China its second largest inbound market only second to its neighbouring country New Zealand; Chinese tourists spent a total of $\$ 9.2$ billion in Australia in 2016, making China the largest market in total spend (Tourism Australia, 2017). To Australian destination marketers, understanding Chinese tourists' behaviours and their perceived destination image of Australia appears utmost important in sustaining Australia's tourism economy (Tourism Australia, 2014; Huang \& Gross, 2010).

Based on a critical interrogation of the relevant literature of tourist behaviour and considering the current Australia-China tourism relations, this present study aims to examine the relationships among perceived destination image, tourist attitude and visit intention and how these relationship can be possibly moderated by gender and generation as two less researched concepts in tourist behaviour studies. The study was conducted in the context of Chinese outbound tourism to Australia. Specifically, the study takes a sample of Chinese urban residents as its subjects. The study has the following three objectives:

1) To explore and identify the salient cognitive destination image factors of Australia perceived by Chinese urban residents;

2) To examine the relationships among Chinese urban residents' perceived destination image of Australia, their attitude toward visiting Australia and their intention to visit Australia; and, 
3) To investigate the moderating roles of gender and generation in the structural relations among perceived destination image, tourist attitude and visit intention among Chinese urban residents.

\section{Literature Review and Hypotheses Development \\ Destination image, attitude and visit intention}

Destination image is one of the most researched concepts in the tourism literature (Pike, 2002; Tasci et al., 2007; Zhang et al., 2014). Many researchers have attempted to define destination image but so far the literature does not show a commonly agreed definition of destination image (Zhang et al., 2014). Generally, destination image refers to the total sum of perceptions, ideals, beliefs, impressions, feelings and expectations of an individual toward a tourist destination (Chon, 1990; Crompton, 1979; Kim and Richardson, 2003). While early studies mostly focussed on the cognitive features of destination image (Echtner \& Ritchie, 1991; Tasci et al., 2007; Martin \& Bosque, 2008), recent conceptualisations and applications have increasingly recognised the cognitive-affective structure of destination image (Tasci et al, 2007; Martin \& Bosque, 2008; Zhang et al., 2014). The cognitive components of destination image denote to the knowledge and beliefs an individual holds regarding the characteristics and attributes of a tourist destination, while the affective dimension of destination image refers to a person's favourable or unfavourable feelings toward the destination (Baloglu, 2000; Kim \& Richardson, 2003). The affective dimension may be more subjective and reflect the overall feelings toward a specific destination; as such, affective image in its nature and dimensionality may not vary across different destinations. However, cognitive image dimensions may be collectively determined by a destination's specific weather, landscape, infrastructure, attraction types and so on. Therefore, cognitive image attributes can vary across different destination contexts and scenarios (Tasci et al., 2007).

Australia's destination image has been examined in a number of studies (e.g., Huang \& Gross, 2010; Murphy, 1999; Son \& Pearce, 2005; Wang \& Davidson, 2010). Assaker (2014) summarised the destination attributes identified in previous studies in measuring Australia's image and identified that the image attributes are in the following categories: Natural and well-known attractions, variety of tourist services and culture, quality of general tourist atmosphere, environment and recreation general environment, and accessibility. To different source markets, a destination's image may change in its meaning and attributes salience due to cultural differences 
(MacKay \& Fesenmaier, 2000). This reflects the complex and dynamic nature of destination image (Gallarza, Saura, \& Garcia, 2002).

Destination image, in its cognitive nature as beliefs and expectations toward a destination, may affect an individual's attitude toward visiting the destination. According to the Theory of Planned Behaviour (TPB) (Ajzen, 1991), an individual's attitude toward a behaviour (e.g., visiting a destination in the future) is determined by the individual's beliefs about such a behaviour. Cognitive destination image factors, as beliefs about the destination, may function well in influencing a potential tourist' attitude toward visiting the destination. In the tourism context, Jalilvand, Samiei, Dini, and Manzari (2012) found that destination image positively influenced tourists' attitude of visiting Iran. Song, You, Reisinger, Lee, and Lee (2014) found that the image of traditional eastern medicine featured in a festival positively affected people's attitude toward attending such a festival. Recently, Park et al. (2017) extended the TPB to study Chinese college students' intention to visit Japan and found that destination image positively affected Chinese college students' attitude toward travelling to Japan. Based on the above discussion, we develop the following hypothesis:

$\mathrm{H}_{1}$ : Perceived destination image positively affects Chinese urban residents' attitude toward visiting Australia

Tourist attitude has been found to be a reliable predictor to visit intention (e.g., Hsu and Huang, 2012; Huang and Hsu, 2009). In numerous studies applying the TPB, attitude was mostly confirmed as a predictor to behavioural intention. Armitage and Conner (2001), based on a metaanalysis of 185 studies applying the TPB in various context, found that attitude collectively explained about one half of the variances of behavioural intention in all the tests. In the tourism context, the predictive power of tourist attitude on visit intention has been confirmed in different empirical studies (Hsu and Huang, 2012; Huang and Hsu, 2009; Lam and Hsu, 2006). As such, we propose the following hypothesis:

$\mathrm{H}_{2}$ : Chinese urban residents' attitude toward visiting Australia positively affects their visit intention

\section{Gender as a moderator of tourist behaviour}


Gender is not only biologically determined but also socially and culturally constructed (Okazaki \& Hirose, 2009). Although gender has been considered as a basis for market segmentation in tourism, very few studies have attended to the relationship between gender and tourism behaviour (Frew and Shaw, 1999). Carr (1999) explicitly noted that gender differences in tourism behaviour had been a neglected area of research. Studies did show differences of tourism behaviour attributed to gender. For instance, Frew and Shaw (1999) found that in terms of actual visitation to a list of named attractions, 7 out of the 31 attractions showed significant differences between males and females; and in terms of interest in visiting these attractions, 9 out of the 31 attractions showed difference between males and females. Research also showed that males and females are different in their online travel information search and use of mobile internet in travel information search (Kim et al., 2007; Okazaki \& Hirose, 2009).

A few studies have identified differences between gender groups in terms of their perceived destination image. Beerli and Martin (2004b) found that among first time international tourists to Lanzarote, an island destination under the sovereignty of Spain, female tourists rated natural/cultural resources and general/tourist leisure infrastructure in the cognitive domain of destination as well as the affective image of the island significantly higher than their male counterparts. In another study, Chen and Kerstetter (1999) identified that women tended to agree on the tourism infrastructure and natural amenity image dimensions in representing a rural tourism destination more than men did.

As a social and psychological construct, gender may also function to moderate some sociopsychological mechanisms underlying tourism behaviour. A recent study by Wang, Qu and Hsu (2016) confirmed that gender played a moderating role in the relationship between affective image and tourist expectations: the effect of affective image on tourist expectations was found to be significantly stronger for female tourists than for male tourists. In the extant literature, gender has been found to be a moderator of the relationships among behavioural constructs (e.g., Beauregard, 2012; Jin, Line, \& Goh, 2013; Karatepe, 2011). For instance, Beauregard (2012) attested that gender moderated the relationship between self-efficacy and organisational citizenship behaviour in the workplace. In consumer behaviour studies, gender has been found to moderate the relationship between service quality and customer satisfaction (cf. Karatepe, 2011; Suki, 2014). 
Specifically, in the hospitality context, Suki (2014) found men and women responded differently to the aspects of a hotel service encounter in making satisfaction judgements. Jin et al. (2013) found that gender moderated the relationship between relationship quality and behavioural loyalty as well as the relationship between attitudinal loyalty and behavioural loyalty. Based on the limited literature support, the current study intends to further test the possible moderation role of gender in the effect of cognitive destination image on tourist attitude and visit intention. To this purpose, we develop the following hypothesis:

$\mathrm{H}_{3}$ : Gender moderates the effects of perceived destination image on tourist attitude and visit intention.

\section{Generation as a moderator of tourist behaviour}

Generational theory posits that a generation is formed as a cohort of people "born over roughly the span of a phase of life who share a common location in history and, hence, a common collective persona" (Strauss \& Howe, 1997, p. 61). People in the same generation usually go through similar social, political events and life experiences and thus form similar ideologies, values and worldviews. In most Western countries, especially the United States, four major generations are identified as the Silent Generation (born before 1945), Baby boomers (born between 1946-1964), Generation X (born between 1965-1980), and Generation Y (born between 1981-1990) (Li et al., 2013; Pendergast, 2009; Strauss \& Howe, 1997). China has undergone significant transitions and changes in its recent and contemporary history; due to a unique political and socio-cultural environment, generations in China may be very different in their worldviews and value system as clearly different (or even contrasting) ideologies and cultural values prevailed in different stages of China's modern history (Yang \& Stening, 2013). Therefore, the terminology of generation studies and the labelling of different generations in the Western society context may not be easily applicable to the context of China. Instead, based on the recent socio-economic development stages of China, some unique generation labelling, such as post-80s (people born in 1980s) or post-90s (people born in 1990s), are more popular and acceptable by the public in China.

Very few studies can be located in examining the moderating role of generation in travel behaviour. In the hospitality management context, Gursoy, Maier and Chi (2008) investigated the generational differences of hospitality employees' work values. Notable differences were found between Baby 
Boomers and Generation X-ers: while Baby Boomers respect authority and hierarchy and live to work, Generation X-ers rebel against authority and work to live. Similarly, Chen and Choi (2008) confirmed the generational differences of work values among hospitality workers. In the tourism context, Li et al.'s (2013) study may be the first to explicitly apply generation theory to examine the generational differences in tourism consumer behaviour. Based on an online panel survey targeting American adult leisure travellers, the study identified significant differences among the four generations (i.e., Silent Gen.; Baby Boomers, Gen X-ers, Gen Y-ers) in all the tested five areas: information sources; destination visitation history; future destination preferences, destination evaluation criteria and travel activity preferences. Li et al.'s study gave sufficient evidence that generations may well serve as a differentiator for various patterns of travel and tourism behaviours.

Although limited, some evidence from the literature supports that generation moderates the relationships between behavioural constructs in different contexts. Studying customer-contact hotel employees, Park and Gursoy (2012) identified that generational differences significantly moderated the effects of work engagement on turnover intention. Gardiner, Grace, and King (2014) studied the three generations (Baby boomer, Gen X, and Gen Y) of Australian travellers in their domestic travel decision making process; Model comparison revealed that the effect of hedonic value on travel attitude was stronger with Baby Boomers that that with Gen X's and Gen Y's. On the other hand, while functional value appeared an insignificant predictor to attitude among Baby Boomers, the effect of functional value on attitude was both positive and significant among Gen X's and Gen Y's. Based on the above literature discussion, we develop the following hypothesis:

$\mathrm{H}_{4}$ : Generation moderates the effects of perceived destination image on tourist attitude and visit intention

The study framework was presented in Figure 1.

\section{(INSERT FIGURE 1 ABOUT HERE)}

\section{Methods}




\section{Construct Measurement}

A questionnaire survey was administered in Harbin, a typical second-tier city in China, to collect data for the study. The key sections of the questionnaire measured Chinese urban residents' perceived destination image of Australia, their attitude toward visiting Australia and their visit intention. Demographic information regarding respondents' gender, age, marital status, education, occupation, and income was also collected.

Perceived destination image items were adapted from Assaker (2014) and Huang and Gross (2010). Assaker (2014) summarized all the possible items measuring Australia's destination image in previous studies and after data purification in his own empirical study, identified 18 items with good measurement qualities in measuring Australia's destination image. Huang and Gross (2010) explored Australia's destination image perceived by Beijing residents through focus groups and identified 16 cognitive image attributes. By collating the two lists of image attributes of Australia in the two studies, we adapted all 18 items in Assaker's study and supplement the list with another 8 items from Huang and Gross's list which show distinctive destination features of Australia and are not well covered by Assaker's list. Altogether, a total of 26 items were used to measure perceived destination image. Six items adapted from Huang and Hsu (2009) were used to measure tourist attitude; three items were adapted from Huang and Hsu (2009) to measure visit intention. All the items were measured using a 7-point Likert scale where $1=$ "strongly disagree" and $7=$ "strongly agree".

\section{Data Collection}

The questionnaire was first developed in English and then translated into Chinese. Back-translation was employed to check whether there was meaning loss or distortion in the translation process. The confirmed Chinese version of questionnaire was used in the survey. The questionnaire survey was conducted in Harbin, a second tier city in China with a registered resident population of 9.87 million (Statistical Bureau of Harbin, 2015). Harbin was considered as the site for data collection as it represents a typical second tier city in China which emerges to send outbound travelers overseas. Recent research has shown that second tier cities in China emerge to be sources sending outbound Chinese tourists (Huang \& Wei, 2018). Therefore, there is a due knowledge need to understand the behaviors of potential Chinese outbound tourists in the emerging source markets. 
As such, we chose a typical tier Chinese city rather than any first tier city in our study. Data collection was completed during the National Day Holiday (1-8 October) in 2014. Students interviewers were recruited from a local university's management school and trained before taking the street intercept survey. Survey teams conducted the survey at a variety of public venues in Harbin city where eligible respondents for the study can be easily found. These places include the Central Street, Harbin Museum, The Sun Island, and the University City. For the purpose of the current study, we set up screening questions to only include those city residents who were over 18 years old and had not visited Australia before in our study sample. It should be noted that convenience sampling is adopted in this study and we did not check whether the respondents were permanent residents or temporary residents in Harbin. Many cities in China host a substantial amount of temporary residents (e.g., university students, seasonal peasants workers). Considering a relevant research ethics issue, we did not include screening questions to differentiate permanent city residents from temporary city residents. A total of 720 questionnaire copies were distributed. After removing 15 copies of unusable copies, 705 copies of valid questionnaires were collected.

\section{Data Analysis}

Of the 705 completed surveys, six cases were removed due to missing data. A final total of 699 valid questionnaires were retained for subsequent statistical analyses. Data analysis was conducted using IBM SPSS version 21. After checking the descriptive statistics of all the items, the whole sample were randomly split into two halves. We then used one half of the sample to run exploratory factor analysis (EFA) on all the construct measurement items and identified the latent factor structures of destination image, attitude and visit intention; this structure was then verified with another half sample using confirmatory factor analysis (CFA). After the image factors were identified, we used the factors in a structural model with tourist attitude and visit intention and tested the structural relations employing the structural equation modelling (SEM) approach. In the final stage, we divided the whole sample into gender groups and generation groups and run multigroup analysis in SEM to test the moderation of gender and generation in the effects of perceived destination image on attitude and visit intention.

\section{Results}

Respondent Profile 
The profile of the respondents is provided in Table 1. The sample was well balanced in terms of gender; $48.8 \%$ of them were male and $51.2 \%$ were female. The majority of respondents $(79.4 \%)$ was between 18-39 years old and over a quarter reported to have no regular income (26.8\%). Majority had completed a 4-year university degree (45.6\%) and over a third of the respondents reported that they were students $(36.5 \%)$. The sample may be overrepresented by young respondents and students. However, considering that these respondents are indeed the future pool of China's outbound tourism market and the study aims to examine visit intention as its dependent variable from a destination marketing perspective, the study sample was thus deemed appropriate for the study.

\section{(INSERT TABLE 1 ABOUT HERE)}

\section{Measurement Model}

Table 2 shows mean values and standard deviations of all the measurement items. Most of the items had a mean value above 5, meaning that respondents showed a high level of agreement with the statements. In order to identify the latent structure that underlies the respondents' specific views towards Australia as a tourism destination, we randomly split the sample $(\mathrm{n}=699)$ into two halves, one used for EFA (calibration sample $n=349$ ) and one for CFA (validation sample $n=350$ ). Although this approach has its limitations, it is generally an accepted method among tourism researchers to generate a reliable factor structure (e.g. Chen, Bao \& Huang, 2014; Kaplanidou \& Vogt; 2006; Kim, Ritchie \& McCormick, 2012). For the EFA, principal component analysis with Varimax rotation was conducted to identify the underlying factors of the research constructs. The Bartlett's Test of Sphericity produced a significant chi-square value of $4538.52(p<.001)$ and the Kaiser-Meyer-Olkin measure of sampling adequacy was .922, indicating that it is suitable to run EFA on the calibration sample. A component was retained if it contained at least two items with a loading larger than 0.45 (Stevens, 2002). In the process of EFA, seven items were removed either because of lower loading or due to double loadings on more than one latent factor. These items are shown at the lower part of Table 2.

The EFA finally extracted five factors with an Eigenvalue greater than 1 and the cumulative extracted variance was 58.04\%. After examining the semantic meanings of the composing items, 
the five extracted components were labeled as: Natural Environment (15.73\%, 9 items), Service \& Tourism Provisions (11.55\%, 6 items), Quality of Life (8.53\%, 4 items), Attitude (13.96\%, 6 items) and Visit Intention (8.27\%, 3 items). The first three factors are perceived destination image factors while the other two correspond to the constructs of tourist attitude and visit intention. This result also indicates the absence of common method variance bias since no single factor explains more than $50 \%$ of the variance (Lowry and Gaskin, 2014).

\section{(INSERT TABLE 2 ABOUT HERE)}

The identified factor structure was then subjected to a confirmatory factor analysis (CFA) with maximum likelihood estimation procedure using the validation sample. The model displayed an acceptable fit $\left(\chi^{2}=998.44, \mathrm{df}=340, \mathrm{p}<0.01, \chi^{2} / \mathrm{df}=2.94, \mathrm{CFI}=0.85, \mathrm{NFI}=0.79, \mathrm{RMSEA}=\right.$ 0.07 ) and the construct reliability (CR) values met the threshold of 0.70 (Hair et al., 2010). The average variance explained (AVE) values for Service and Tourism Provisions, Natural Environment and Quality of Life are below 0.50. However, Fornell and Larcker (1981) note that the AVE score is rather a conservative measure and convergent validity of the construct is adequate on the basis of composite reliability alone. Therefore, considering that the composite reliability scores of the three factors meet the minimum level of .70, the measurements of these factors can still be regarded as having sufficient convergent validity.

Table 3 displays the correlation matrix for the factors as well as the square root of the AVE scores (reported in the diagonal and bold) to verify discriminant validity (Fornell \& Larcker 1981). Most diagonal values were greater than the off-diagonal values, indicating that each factor shares more variance with its measures than it shares with other constructs and suggesting adequate evidence of discriminant validity.

However, Quality of Life seems to display multicollinearity problems. For a closer examination of this issue, the variance inflation factor (VIF) scores were inspected. The three image factors, Service and Tourism Provisions (VIF = 2.59), Natural Environment (VIF = 4.59) and Quality of Life $(\mathrm{VIF}=6.83$ ) have VIFs less than 10 (Hair et al., 2010; Pallant, 2010; Tabachnick \& Fidell, 2013). So the multicollinearity issue was not so serious to distort the study findings. 
(INSERT TABLE 3 ABOUT HERE)

\section{Structural Model and Hypothesis Testing}

The hypothesized relationships among perceived image factors, tourist attitude and visit intention were subsequently tested using structural equation modelling with IBM AMOS version 21. The results are presented in Figure 2. Overall, the structural model showed an acceptable fit $\left(\chi^{2}=\right.$ 1268.36, $\left.\mathrm{df}=343, \mathrm{p}<0.01, \chi^{2} / \mathrm{df}=3.70 ; \mathrm{CFI}=0.89 ; \mathrm{NFI}=0.86 ; \mathrm{RMSEA}=0.06\right)$. The results indicate that two of the three destination image factors, i.e., Service and Tourism Provisions $(\gamma=$ 0.25; $t$-value $=4.51)$, Natural Environment $(\gamma=0.43 ; t$-value $=5.95)$, had a significant positive effect on Attitude; however, the effect of Quality of Life as an image factor on Attitude was not statistically significant $(\gamma=0.11 ; t$-value $=1.25)$. Taken together, sufficient evidence shows that $\mathrm{H}_{1}$ was mostly supported, especially when the image factors are directly related to tourism (e.g., tourism provisions, natural environment forming the basis for tourism attractions). Furthermore, the combined explanatory effect of the three image factors (Natural Environment, Service \& Tourism Provisions, Quality of Life $)$ on Attitude was quite substantial $\left(\mathrm{R}^{2}=0.50\right)$. Not surprisingly, Attitude $(\beta=0.72 ; t$-value $=16.46)$ had a quite strong effect on Visit Intention explaining half of its variance $\left(\mathrm{R}^{2}=0.51\right)$. Thus, $\mathrm{H}_{2}$ was supported.

\section{(INSERT FIGURE 2 ABOUT HERE)}

\section{Moderation Testing}

As the next step of our data analysis, we examined the moderating roles of gender and generation in the structural relationships among perceived image, attitude and visit intention. To facilitate the statistical tests we used parceling for the three image predictors (Service and Tourism Provisions, Natural Environment, Quality of Life). Parceling helps to reduce the complexity of the structural model and assumes that the survey items within each parcel are unidimensional (Kline 2011). Previous results in the principal component analysis have verified that the image factors are unidimensional and that the survey items strongly correlate with the underlying constructs. 
The nine measurement items for Service and Tourism Provisions were parcelled into three items whereby each parcelled item consisted of three original survey items. The six survey items for Natural Environment was parcelled into three items whereby each parcelled item consisted of two survey items; and the four survey items for Quality of Life were combined equally into two parcels.

Generally, moderation effect can be either tested in regression by introducing the interaction term between the predictor variable and moderator variable in the regression model, or examined in the structural equation modelling approach through multi-group analysis of structural equation modelling (SEM) (Byrne, 2016). As our model is a typical structural model, we employed multigroup analysis in SEM to test the moderation effect. Multi-group function in IBM AMOS version 21 was used to conduct the group difference analysis.

The gender groups (Male group $n=341$; Female group $n=358$ ) were well balanced and sufficiently large for structural modelling purposes and achieved an excellent overall fit $\left(\chi^{2}=\right.$ 379.95 , df $\left.=140, \mathrm{p}<0.01, \chi^{2} / \mathrm{df}=2.71 ; \mathrm{CFI}=0.95 ; \mathrm{NFI}=0.92 ; \mathrm{RMSEA}=0.05\right)$. To create distinctive and equivalent-size generation groups, we randomly select one-third of the respondents who reported their age in the 18-29 years old group and formed the younger generation group $(n=132)$. This group was compared with the 40-49 years old group $(n=98)$, leaving 10 years age gap between the two groups. The younger generation group members were those respondents born between 1985 and 1996, thus can be regarded as the Post-80s/90s generation (roughly equivalent to Gen Y by birth years); and the older generation group members were those respondents born between 1965 to 1974, normally called Post-60s/70s in China (equivalent to Gen X by birth years). The sample size for the two generational groups were relatively small but nevertheless sufficient for structural modelling purposes since the number of estimated parameters in the structural model has been greatly reduced due to parceling. The two generational group structural model achieved an acceptable fit $\left(\chi^{2}=266.91, \mathrm{df}=140, \mathrm{p}<0.01, \chi^{2} / \mathrm{df}=1.91 ; \mathrm{CFI}=0.93 ; \mathrm{NFI}=0.86 ; \mathrm{RMSEA}=\right.$ 0.06). Table 4 shows the group difference test results with the structural path coefficients and the z-scores using two different approaches to data treatment of creating the parcels for the three image factors. The first approach uses factor scores obtained from a principal component analysis and the second approach uses the grand mean values of the original survey items. The results of both 
approaches are highly consistent and show the robustness to the group difference test results. In addition, we also tested the group differences of mean scores for each of the five latent constructs; none of the five constructs exhibited significant difference in their latent mean score between the gender groups and between the generational groups.

When looking at the approach using the factor scores, gender group comparison shows that the path coefficient from Service and Tourism Provisions to Attitude and that from Natural Environment to Attitude were significantly different between males and females. The coefficient from Service and Tourism Provisions to Attitude for females (.15) was much lower than that for males (.31). This shows the effect of image factor Service and Tourism Provisions on tourist attitude is significant stronger for males than females. Contrastingly, the effect of Natural Environment on Attitude for females (.47) was much stronger than that for males (.29). Although the coefficients are slightly different, the same pattern of results was found when using simple averages to replace factor scores for the constructs.

For the comparison between the two generational groups, significant difference was found between the two groups regarding the effect of Natural Environment on Attitude. The path coefficient from Natural Environment to Attitude for the Post-80s/90s generation group (.45) was much higher than that for the Post-60s/70s generation group. Identical results were found when grand average scores are used for parcelling (Table 4).

In summary, as significant differences were confirmed between the gender groups as well as the generational groups with regards to the effects of perceived destination image factors on tourist

attitude, $\mathrm{H}_{3}$ and $\mathrm{H}_{4}$ were supported with empirical evidence in the study. However, we would like to note that the effect of tourist attitude on visit intention did not show any variation either between the gender groups or between the generational groups.

\section{(INSERT TABLE 4 ABOUT HERE)}

\section{Discussion and Conclusions}


This study examines the relationships among destination image, tourist attitude, and visit intention with Chinese urban residents taking Australia as a tourist destination and how these relationships are moderated by gender and generation. The study generated image items based on previous relevant studies and a total of 26 image measurement items were adapted from the literature. 19 out of the 26 items were retained to confirm three image factors of Australia as a tourist destination among Chinese urban residents living in Harbin. These image factors are Services and Tourism Provisions, Natural Environment, and Quality of Life. Further structural equation modelling analyses reveal that two image factors, Services and Tourism Provisions and Natural Environment significantly affected Chinese urban residents' attitude toward visiting Australia, which in turn significantly affected their intention to visit Australia.

Compared to Assaker's (2014) study, the current study generated relatively few image factors. However, except for Quality of Life, the image factors identified in this study are mostly consistent with those in Assaker's (2014) study. The difference in number of image factors may be explained by the difference of the study samples. Assaker (2014) used an online panel data including respondents from UK, USA, China and South Korea. The heterogeneity of his sample may have contributed to the more varied image factors in his study. In the current study, respondents are from a single city in China and without any previous direct travel experience in Australia. The nature of the sample may explain why relatively few image factors were identified and technically the AVEs of the measurements are relatively low. As the Quality of Life dimension mainly reflects the respondents' perception of Australia as a country in general and not closely related to tourist experience, this image factor was found not exerting any influence on tourist attitude. This finding bears both theoretical and practical implications. Theoretically, it points to the fact that cognitive image factors or attributes have differentiated roles in soliciting actual visitations. Some image factors may be better predictors to actual visitations than others. Practically, from a destination marketing point of view, destination marketing organisations (DMOs) should focus more on those image factors that can foster favourable attitude and create future visitation in their marketing campaigns.

On the marketing knowledge side, this study identified Services and Tourism Provisions, Natural Environment, and Quality of Life as three salient image factors of Australia among potential 
mainland Chinese visitors. Studying potential tourists' image of a target destination is important in that it can disclose valuable knowledge for market development in destination marketing. Although Australia's destination image has been examined in various studies (Assaker, 2014; Huang \& Gross, 2010; Murphy, 1999; Son \& Pearce, 2005; Wang \& Davidson, 2010), the current study's dedication to the potential market in a second tier city in China still present unique image features specific to this market.

Through group comparisons in structural equation modelling, this study found significant differences between males and females regarding the two image factors' effects on attitude. Specifically, for males, the effect of Services and Tourism Provisions on Attitude was much stronger than that for females; however, the effect of Natural Environment on Attitude was stronger for females than that for males. In this regard, the current study provide contradictory findings to that of Wang et al.'s study (2016). Wang et al.'s study did not support their hypothesis that the influence of cognitive image on tourist expectation is stronger for females than for males. Our study, however, revealed mixed findings. Gender's moderation in the effect of cognitive image on tourist attitude may be determined by the nature of cognitive destination image features themselves. While some destination image components (e.g., services and tourism provisions) may reflect more functional value in tourists' expected experiences, others (e.g. natural environment) may convey more of the emotion value in making tourist experiences. Williams and Soutar (2000) found that consumer value dimensions in tourism experience include functional, emotional, social and epistemic. Accordingly potential consumers/tourists may attribute different types of image dimensions as conveying different natures of customer value. Wang et al. (2016) did find that the effect of affective image on tourist expectation is stronger for females than for males. This is consistent to a certain extent to our finding that the effect of Natural Environment (if mainly generating emotional value of tourism experience) on Attitude. The general psychological literature shows that women are generally more emotional and empathetic then men (e.g., Barrett, Robin, Pietromonaco, \& Eyssell, 1998; Mestre, Samper, Frias, \& Tur, 2009). This offers some clues to explain why affective image or cognitive image domains that contribute to more emotional values would strengthen women's attitude and visit intention. 
This study also found that the effect of Natural Environment on Attitude was much stronger for the Post-80s/90s generation than for the Post-60s/70s generation in China. As generations are moulded within a certain social and cultural context, it is necessary to go into the social context to understand generational differences. In China, the younger generation normally face more social and economic pressure in their life than the older generations. When considering outbound holiday, those destination features like natural environment that may create a relaxation and refreshing effect may be more appealing to the younger generation in China.

This study highlights the importance of gender and generation in the tourism decision making process. Although some studies have examined the roles of gender and generation in tourist behaviours (Beauregard, 2012; Gardiner et al., 2014; Jin, Line, \& Goh, 2013; Karatepe, 2011; Li et al., 2013; Park \& Gursoy, 2012; Suki, 2014), very little knowledge has been developed in understanding how gender and generation function in differentiating tourist behaviours. The current study, together with a limited number of previous studies in the tourism field, provides empirical evidence that gender and generation moderate tourist decision making process. The study thus makes a distinctive contribution to the literature in leading the attention to gender theory and generation theory in studying tourist behaviour. Based on our findings, we call for further indepth investigations into the roles of gender and generation in tourist behaviour studies.

\section{Marketing Implications}

In its study context, this research offers valuable marketing implications to destination marketing organisations in Australia when targeting the Chinese tourist market. This study shows that different destination image dimensions function differently to influence Chinese tourists' attitude and visit intention. Services and tourism provisions and natural environment are more prominent to affect attitude, while quality of life perception exerts no influence on attitude. Australian destination marketers should therefore focus more on projecting the image of tourism provisions and natural environment in their marketing communications and promotion campaigns to the China market. Specifically, to women travellers, they may stress the natural environment image of Australia or those image features that can trigger more emotional resonance; but for men travellers, marketing efforts can focus on the functional value projected by images of tourism provisions and services facilities (sports, entertainment, nightlife, souvenirs). To target the Post-80s/90s travellers 
in China, Australia can further strengthen its image of natural beauty and landscape, beaches, native animals and vegetation, good climate and clean environment. This will sustain Australia's attraction power and help attract more future travellers from China.

\section{Limitation and Future Research}

This study has its limitations. First of all, we used convenience sampling and only included the residents of one mainland city in China. Although Harbin can be regarded as a typical second tier city in China, the sample is limited and cannot be deemed representative to all Chinese urban residents. Future research could apply a nation-wide stratified sampling to make a more representative sample if funding and resources are available. Second, even though the whole sample is large, when testing generational differences, the subgroup sample size has been greatly reduced. This technically prevented us from testing the possible interaction effect between gender and generation. Future studies may circumvent such a constraint and apply better sample design to test the interaction effect between gender and generation. Lastly, this study only examined the moderation of gender and generation in the effects of destination image on tourist attitude and visit intention. Future studies could expand to test the moderating roles of gender and generation to other tourist behavioural determination mechanisms (e.g., effects of motivation and expectation on tourist loyalty, effects of destination personality, self-congruity on visit intention). 


\section{References}

Ajzen, I. (1991). The theory of planned behaviour. Organizational Behavior and Human Decision Processes, 50, 179-211.

Armitage, C.J., \& Conner, M. (2001). Efficacy of the Theory of Planned Behavior: A Metaanalytic Review. British Journal of Social Psychology, 40(4), 471-99.

Assaker, G. (2014). Examining a hierarchical model of Australia's destination image. Journal of Vacation Marketing, 20(3), 195-210.

Baloglu, S. (2000). A path analytic model of visitation intention involving information sources, socio-psychological motivations and destination image. Journal of Travel and Tourism Marketing, 8(3), 81-91.

Baloglu, S., \& McCleary, KW. (1999). A model of destination image formation. Annals of Tourism Research, 26(4), 868-897.

Barrett, L.F., Robin, L., Pietromonaco, P.R., \& Eyssell, K.M. (1998). Are women the "more emotional" sex? Evidence from emotional experiences in social context. Cognition and Emotion, 12(4), 555-578.

Beauregard, T.A. (2012). Perfectionism, self-efficacy and OCB: the moderating role of gender. Personnel Review, 41(5), 590-608.

Beerli, A., \& Martin, J.D. (2004a). Factors influencing destination image. Annals of Tourism Research, 31(3), 657-681.

Beerli, A., \& Martin, J.D. (2004b). Tourists' characteristics and the perceived image of tourist destinations: a quantitative analysis - a case study of Lanzarote, Spain. Tourism Management, 25, 623-636.

Byrne, B. M. (2016). Structural equation modeling with AMOS: basic concepts, applications and programming (3rd ed.). New York, NY: Routledge.

Carr, N. (1999). A study of gender differences: young tourist behaviour in a UK coastal resort. Tourism Management, 20, 223-228.

Chen, C.-F., \& Tsai, D.C. (2007). How destination image and evaluative factors affect behavioural intentions? Tourism Management, 28, 1115-1122.

Chen, G., Bao, J. and Huang, S. (2014) Developing a scale to measure backpackers' personal development. Journal of Travel Research 53(4), 522- 536. 
Chen, P.J., \& Choi, Y. (2008). Generational differences in work values: a study of hospitality management. International Journal of Contemporary Hospitality Management, 20(6), 595615.

Chen, P.J., \& Kerstetter, D.L. (1999). International students' image of rural Pennsylvania as a travel destination. Journal of Travel Research, 37, 256-266.

Chew, E.Y.T., \& Jahari, S.A. (2014). Destination image as a mediator between perceived risks and revisit intention: A case of post-disaster Japan. Tourism Management, 40, 382-393.

Chon, K.-S. (1990). The role of destination image in tourism: A review and discussion. The Tourist Review, 45(2), 2-9.

Crompton, J.L. (1979). An assessment of the image of Mexico as a vacation destination and the influence of geographical location upon the image. Journal of Travel Research, 18(4), 1823.

Echtner, C.M., \& Ritchie, J.R.B. (1991). The meaning and measurement of destination image. Journal of Tourism Studies, 2(2), 2-12.

Fornell, C., \& Larcker, D.F. (1981). Evaluating structural equation models with unobservable variables and measurement error. Journal of Marketing Research, 18(1), 39-50.

Frew, E.A., \& Shaw, R.N. (1999). The relationship between personality, gender, and tourism behaviour. Tourism Management, 20, 193-202.

Gallarza, M.G., Saura, I.G., \& Garcia, H.C. (2002). Destination image: Towards a conceptual framework. Annals of Tourism Research, 29(1), 56-78.

Gardiner, S., Grace, D., \& King, C. (2014). The generation effect: the future of domestic tourism in Australia. Journal of Travel Research, 53(6), 705-720.

Gursoy, D., Maier, T.A., \& Chi, C. G. (2008). Generational differences: An examination of work values and generational gaps in the hospitality workforce. International Journal of Hospitality Management, 27(3), 448-458.

Hair Jr, J. F., Black, J. W., Babin, B. J., \& Anderson, E. R. (2010). Multivariate Data Analysis (7 ${ }^{\text {th }}$ ed.). Edinburgh: Pearson Education Limited.

Han, H., Meng, B., \& Kim, W. (2017). Bike-traveling as a growing phenomenon: Role of attributes, value, satisfaction, desire and gender in developing loyalty. Tourism Management, 59, 91-103. 
Hsu, C.H.C., \& Huang, S. (2012). An extension of the Theory of Planned Behaviour model for tourists. Journal of Hospitality and Tourism Research, 36(3), 390-417.

Huang, S., \& Gross, M. (2010). Australia's destination image among mainland Chinese travellers: An exploratory study. Journal of Travel and Tourism Marketing, 27(1), 63-81.

Huang, S., \& Hsu, C.H.C. (2009). Effects of travel motivation, past experience, perceived constraint, and attitude on revisit intention. Journal of Travel Research, 48(1), 29-44.

Huang, S., Wei, X. (2018). Chinese outbound travel: understanding the socioeconomic drivers. International Journal of Tourism Research, 20 (1), 25-37.

Jalilvand, M.R., Samiei, N., Dini, B., \& Manzari, P.Y. (2012). Examining the structural relationships of electronic word of mouth, destination image, tourist attitude toward destination and travel intentioin: An integrated approach. Journal of Destination Marketing and Management, 1(1-2), 134-143.

Jin, N., Line, N.D., \& Goh, B. (2013). Experiential value, relationship quality, and customer loyalty in full-service restaurants: the moderating role of gender. Journal of Hospitality Marketing and Management, 22(7), 679-700.

Karatepe, O.M. (2011). Service quality, customer satisfaction and loyalty: the moderating role of gender. Journal of Business Economics and Management, 12(2), 278-300.

Kaplanidou, K., \& Vogt, C. (2006). A structural analysis of destination travel intentions as a function of website features. Journal of Travel Research, 45(2), 204-216.

Kim, D.-Y., Lehto, X.Y., \& Morrison, A.M. (2007). Gender differences in online travel information search: Implications for marketing communications on the internet. Tourism Management, 28, 423-433.

Kim, H., \& Richardson, S.L. (2003). Motion picture impacts on destination images. Annals of Tourism Research, 30(1), 216-237.

Kim, J., J. B. Ritchie, and B. McCormick. 2012. Development of a Scale to Measure Memorable Tourism Experiences. Journal of Travel Research, 51(1), 12-25

Kline, R. B. (2015). Principles and Practice of Structural Equation Modeling (4 ${ }^{\text {th }}$ ed.). New York: The Guilford Press.

Lam, T. \& Hsu, C.H.C. (2006). Predicting behavioural intention of choosing a travel destination. Tourism Management, 27(4), 589-599. 
Li, X., Li, X.R., \& Hudson, S. (2013). The application of generational theory to tourism consumer behaviour: An American perspective. Tourism Management, 37, 147-164.

Lowry, P.B., \& Gaskin, J. (2014). Partial least square (PLS) structural equation modelling (SEM) for building and testing behavioral casual theory: when to choose it and how to use it. IEEE Transactions on Professional Communication, 57(2), 123-146.

Martin, H.S., \& Bosque, I.A.R. (2008). Exploring the cognitive-affective nature of destination image and the role of psychological factors in its formation. Tourism Management, 29, 263277.

MacKay, K.J. \& Fesenmaier, D.R. (2000). An exploration of cross-cultural destination image assessment. Journal of Travel Research, 38, 417-423.

Mestre, M.V., Samper, P., Frias, M.D., \& Tur, A.M. (2009). Are women more empathetic than men? A longitudinal study in Adolescence. The Spanish Journal of Psychology, 12(1), 7683.

Murphy, L. (1999). Australia's image as a holiday destination - perceptions of backpacker visitors. Journal of Travel and Tourism Marketing, 8(3), 21-45.

Okazaki, S. \& Hirose M. (2009). Does gender affect media choice in travel information search? On the use of mobile Internet. Tourism Management, 30, 794-804.

Park, J., \& Gursoy, D. (2012). Generation effects on work engagement among U.S. hotel employees. International Journal of Hospitality Management, 31, 1195-1202.

Park, S.H., Hsieh, C.-M. \& Lee, C.-K. (2017). Examining Chinese college students' intention to travel to Japan using the extended theory of planned behaviour: Testing destination image and the mediating role of travel constraints. Journal of Travel and Tourism Marketing, 34, 113-131.

Phillips, W.J., Asperin, A., \& Wolfe, K. (2013). Investigating the effect of country image and subjective knowledge on attitudes and behaviors: U.S. Upper Midwesterners' intentions to consume Korean food and visit Korea. International Journal of Hospitality Management, $32,49-58$.

Pendergast, D. (2009). Generational theory and home economics: future proofing the profession. Family and Consumer Sciences Research Journal, 37(4), 504-522.

Pike, S. (2002). Destination image analysis - a review of 142 papers from 1973 to 2000. Tourism Management, 23, 541-549. 
Pallant, J. (2010). SPSS survival manual: A step by step guide to data analysis using SPSS (4th ed.). Australia: Allen \& Unwin Book Publishers.

Son, A., \& Pearce, P. (2005). Multi-faceted image assessment: international students' views of Australia as a tourist destination. Journal of Travel and Tourism Marketing, 18(4), 21-35.

Song, H., You, G.-J., Reisinger, Y., Lee, C.-K., \& Lee, S.-K. (2014). Behavioral intention of visitors to an Oriental medicine festival: An extended model of goal directed behaviour. Tourism Management, 42, 101-113.

Statistical Bureau of Harbin. (2015). 2014 Harbin City National Economy and Social Development Statistical Report. Retrieved June 1, 2017, from http://www.harbin.gov.cn/info/news/index/detail/412865.htm

Stevens, J. P. (2002). Applied multivariate statistics for the social sciences (4th ed.). Hillsdale, NJ: Erlbaum.

Strauss, W., \& Howe, N. (1997). The fourth turning: An American prophecy. New York: Broadway Books.

Suki, N.M. (2014). Moderating role of gender in the relationship between hotel service quality dimensions and tourist satisfaction. Journal of Quality Assurance in Hospitality \& Tourism, 15(1), 44-62.

Tabachnick, B. G., \& Fidell, L. S. (2013). Using Multivariate Statistics (6th ed.). New Jersey: Pearson Education Inc.

Tasci, A.D.A., Gartner, W.C., \& Cavusgil, S.T. (2007). Conceptualization and operationalization of destination image. Journal of Hospitality and Tourism Research, 31(2), 194-223.

Tavitiyaman, P., \& Qu, H. (2013). Destination image and behaviour intention of travellers to Thailand: the moderating effect of perceived risk. Journal of Travel and Tourism Marketing, 30, 169-185.

Tourism Australia. (2014). Understanding the Chinese consumer. Retrieved June 2, 2017 from http://www.tourism.australia.com/documents/Statistics/Consumer-demand-projectCHINA.pdf

Tourism Australia. (2017). China Market Profile 2017. Retrieved June 2, 2017 from http://www.tourism.australia.com/documents/Markets/TASI11145_Market_Profiles_2017_ China_Full-V5(1).pdf 
Wang, C., Qu, H., \& Hsu, M.K. (2016). Toward an integrated model of tourist expectation formation and gender difference. Tourism Management, 54, 58-71.

Wang, Y., \& Davidson, M.G.C. (2010). Pre- and post-trip perceptions: an insight into Chinese package holiday market to Australia. Journal of Vacation Marketing, 16(2), 111-123.

Williams, P., \& Soutar, G.N. (2000). Dimensions of customer value and the tourism experience: an exploratory study. In proceedings of ANZAC 2000 Conference: Visionary Marketing for the $21^{\text {st }}$ Century: Facing the challenge, pp. 1415-1421.

Yang, S., \& Stening, B. (2013). Mao meets the market: Reconciling and pragmatism in China. Management International Review, 53(3), 419-448.

Zhang, H., Fu, X., Cai, L.A., \& Lu, L. (2014). Destination image and tourist loyalty: A metaanalysis. Tourism Management, 40, 213-223. 